\title{
Sistem Tektonik Dan Implikasinya Terhadap Gempa Bumi Di Pulau Halmahera
}

\author{
Alwi La Masinu*, Arisius Yustesia*, Suwardi** \\ * Program Studi Pendidikan Geografi STKIP Kie Raha Ternate \\ ** Badan Meteorologi Klimatologi dan Geofisika, Stasiun Geofisika, Ternate
}

\section{INFO ARTIKEL}

Riwayat Artikel:

Diterima: 19-Januari-2017

Disetujui: 31-Oktober-2017

\section{Kata kunci:}

Tektonik; Gempa Bumi;

Pulau Halmahera

\author{
Alamat Korespondensi: \\ Alwi La Masinu \\ Program Studi Pendidikan Geografi \\ STKIP Kie Raha Ternate \\ Ternate 97751 \\ E-Mail: alwi_lamasinu@yahoo.com
}

\section{PENDAHULUAN}

Secara tektonik wilayah Maluku Utara dan Maluku merupakan daerah tektonik yang kompleks. Hal ini disebabkan oleh interaksi tiga lempeng besar diantaranya lempeng Eurasia di sebelah barat, lempeng Indo-Australia di bagian Selatan dan lempeng Pasifik di bagian timur, dan lempeng mikroMindanao di bagian utara. 


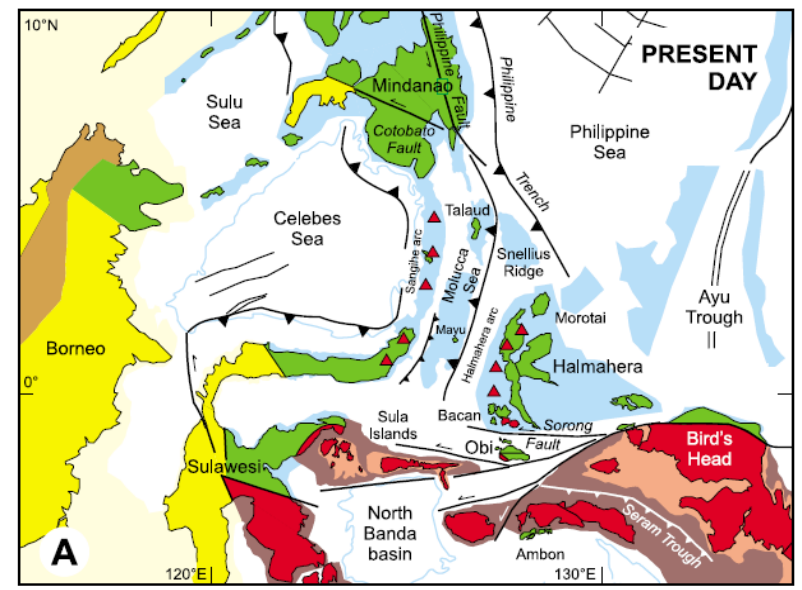

Gambar 1. Sistem tektonik regional Pulau Halmahera dan sekitarnya (Hall, 2000)

Secara tektonik Maluku Utara merupakan suatu wilayah yang memiliki tingkat kegempaan yang cukup tinggi dan kompleks, hal ini di pengaruhi tiga lempeng besar yaitu lempeng Eurasia lempeng Pasifik dan lempeng Indo-Australia bertemu di wilayah Halmahera (Ballantyne, 1991). Pertemuan dari beberapa lempeng tersebut menyebabkan saling mendorong antara satu dengan yang lain menjadikan wilayah Maluku Utara memiliki potensi kegempaan yang cukup aktif (Condie, 2016; Lourenço et al., 2016; Nakagawa dan Spiegelman, 2017).

Di bagian utara dari arah Maluku Utara terdapat beberapa lempeng mikro yang mempengaruhi seismisitas di kawasan ini yaitu busur kepulauan Halmahera, Sangihe dan lempeng mikro di laut Maluku. Ketiga lempeng mikro ini merupakan serpihan margin dari mega lempeng Eurasia dan Pasifik yang saling menekan. terlebih lagi lempeng Laut Maluku yang mencirikan pola seismisitas yang kompleks sebagai sumber tekanan yang begitu besar.

Sementara di bagian selatan terdapat sesar yang memanjang dari kepala burung di wilayah Papua hingga menuju kepulauan Banggai sulawesi tengah. sesar ini terlihat sebagai batas tektonik antara kawasan Maluku Utara yang dipengaruhi oleh lempeng Eurasia dan Pasifik dan kawasan tektonik berada di bagian selatannya yang dipengaruhi oleh lempeng Indo-Australia. sesar ini merupakan sesar mengiri (left lateral) yang strike slip di Halmahera bagian selatan, sesar ini melewati beberapa wilayah yaitu Kepulauan Bacan, Pulau Obi dan Kepulauan Sula (Hall, 2000).

Keberadaan Halmahera sebagai lempeng tektonik yang di pisahkan dari lempeng laut Maluku dan Sangihe. Hal yang tampak saat ini adalah Halmahera merupakan bagian dari perpanjangan Laut Maluku yang bersubduksi pada masa Neogene antara 45 dan 25 juta tahun yang lalu (Hillis dan Muller, 2003).

Tingkat seismisitas menunjukkan bahwa lempeng Halmahera mencapai kedalaman sekitar $200 \mathrm{~km}$ dan Sangihe maupun Halmahera terekspos kepermukaan, sedangkan lempeng Laut Maluku sepenuhnya tenggelam dibawah dua lempeng mikro (Widiwija yanti et al., 2003).Batas selatan Lempeng Laut Maluku juga merupakan batas Lempeng Laut Filipina dan Lempeng Australia. Batas tersebut bergerak ke atas. Karena Lempeng Sangihe dan Halmahera bersambung dengan Lempeng Laut Maluku, ini berarti ketiga sambungan tersebut bergerak keutara di bagian mantel bersam alempeng Australia. Pada zona yang luas dan berkecepatan tinggi dibawah Lempeng kepala Burung mencapai kedalaman 400-600 km diperkirakan sebagai sisa sambungan yang bersubduksi di bawah lempeng Halmahera. Zona luas berkecepatan tinggi lainnya di bawah Laut Sulawesi dengan kedalaman mencapai 700-1000 km, diperkirakan sebagai sisa sambungan dibawah Lempeng Sangihe. Kedua sisa 
tersebut berasal dari sambungan yang bersubduksi di bawah Busur Filipina-Halmahera 45 sampai 25 juta tahun yang lalu (Hall dan Spakman, 2015).

Tujuan penelitian dilakukan adalah untuk mengetahui sistem tektonik dan implikasinya terhadap gempa bumi dan kerusakan bangunan di pulau Halmahera.

\section{METODE}

Penelitian ini dilakukan di Badan Meteorologi Klimatologi dan Geofisika Stasiun Ternate tahun 2015, yang secara adiministrasi beradadi kecamatan Ternate Utara (Kota Ternate). Objek penelitian tentang sistem tektonik dan implikasinya terhadap gempa bumi di pulau Halmahera di rekam melalui peralatan seismograf dengan memanfaatkan sistem jaringan Libra (Indonesia), Geofon (Jerman) dan lain-lain sebagainya yang bertujuan untuk mendaptkan informasi gempa bumi di Maluku Utara, yang akan di keluarkan melalui validasi parameter, prosesnya yaitu pencocokan informasi dengan laman index, GFZ, United States Geological Survey (USGS) dan informasi gempa bumi dari Pusat Gempa Bumi Regional (PGR) Manado. Setelah data di peroleh dari stasiun BMKG Ternate di berikan interprestasi secara sederhana yaitu menggunakan analisis deskriptif dan diuraikan secara detail, dan tidak menggunakan sofware atau aplikasi.

\section{A. Gempa Bumi di Tahun 2015}

\section{HASIL DAN PEMBAHASAN}

Wilayah Maluku Utara merupakan daerah tektonik yang sangat aktif dan kompleks di kawasan ini di sebakan oleh hasil interaksi dari ketiga lempeng besar yaitu lempeng Pasifik, lempeng Eurasia dan lempeng Indo-Australia di kawasan Maluku Utara yang berlangsung dalam jangka waktu cukup lama. Sehingga memicu stabilitas batuan menjadi lebih labil, situasi dan kondisi seperti ini akan berpotensi untuk menimbulkan gempa bumi dalam jumlah yang banyak di kawasan Maluku Utara. Dari beberapa lempeng tektonik dan lempeng mikro di bagian utara, menyebabkan wilayah Halmahera akan rawan gempa-gempa tektonik yang cukup tinggi terutama terjadi pada zona-zona subduksi. Pertemuan dari beberapa lempeng tektonik dapat menyebabkan saling mendorong antara satu dengan lainnya, menjadikan kawasan Maluku Utara dan Halmahera akan aktif sistem sesar terutama terjadi pada busur kepulauan Halmahera. Di tahun 2015 telah terjadi gempa bumi sebanyak 2.125 kali. Gempa bumi ini telah direkam melalui Stasiun Badan Meteorologi Klimatologi dan Geofisika Ternate. Kejadian gempa bumi yang telah dianalisis menunjukkan sebagai aktifitas seismisitas terbesar di kawasan Maluku Utara dengan berpusat pada kejadian di Kabupaten Halmahera Barat. 


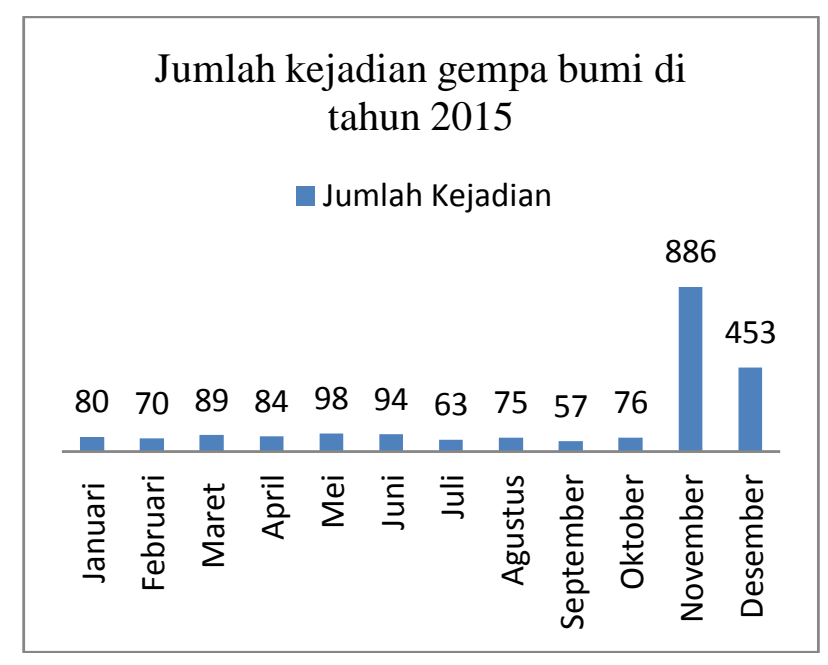

Gambar 2. Histogram Jumlah Kejadian Gempa Bumi Kabupaten Halmahera Barat Di Tahun 2015

Tingkat kegempaan yang tinggi di bulan november dan desember sebannyak 886 hingga 453 kejadian, paling rendah di bulan september 57 kali kejadian, kegiatan seismisitas mengikuti tatanan tektonik Maluku Utara (Sulaeman and Cipta, 2012). Seismisitas yang dapat dirasakan secara langsung terjadi di tahun 2015 pada bulan agustus yang tercatat 75 kali.

Maluku Utara merupakan wilayah yang cukup banyak telah memproduksi gempa bumi tipe (swarm) (Gunawan et al., 2017). Selama tahun 2015 gempa bumi terjadi di kecamatan Jailolo Kabupaten Halmahera Barat yang menjadi penyumbang terbesar aktivitas gempa yang terjadi untuk di wilayah ini. selain gempa bumi tipe ini, sumber gempa bumi terdapat di laut Maluku, Pulau Halmahera, sesar Sorong-Sula di Halmahera Selatan dan di daerah Morotai.

Kawasan laut Maluku dikenal sebagai salah satu kawasan dengan tingkat seismisitas yang paling aktif di Indonesia. aktifitas gempa di bagian ini berkaitan dengan zona subduksi ganda, yakni subduksi dari lempeng Pasifik melalui busur Halmahera yang menunjam ke arah barat, dan subduksi lempeng Eurasia melalui busur Sangihe yang menunjam ke arah timur. Gempa bumi yang berpusat di kawasan ini lebih dominan gempa bumi berkedalaman dangkal (h $<30 \mathrm{~km})$.

Pulau Halmahera merupakan sebuah pulau yang terbesar dari gugusan kepulauan Maluku Utara. Sering terjadi gempa bumi dalam hingga gempa bumi dangkal. Hal ini desebabkan karena penunjaman lempeng laut Maluku di sebelah barat pantai Halmahera. Berdasarkan keadaan geologi wilayah Halmahera dapat di bagi menjadi dua bagian yaitu Halmahera bagian barat dan Halmahera bagian timur laut-tenggara. Halmahera bagian barat merupakan yang tersusun dari busur vulkanik Ternate, sedangkan Halmahera bagian timur laut-tenggara merupakan yang tersusun dari Melange. Kabupaten Halmahera Barat dan Kabupaten Halmahera Timur sebagai kepulauan Maluku Utara merupakan wilayah yang terdiri atas pulau-pulau vulkanik dan pulau non vulkanik. Pulau vulkanik menempati bagian barat, yakni Pulau Ternate, Pulau Tidore, Pulau Moti, Pulau Mare, Pulau Makian, dan Pulau Sangihe. Sedangkan pulau non-vulkanik yaitu Pulau Bacan, Pulau Kasiruta, Pulau Talaud, dan Pulau Obi (Hall dan Spakman, 2015).

Gempa bumi yang terjadi di kawasan (Jailolo) Kabupaten Halmahera Barat sering berasosiasi dengan aktifitas magmatik (vulkanik) maupun non magmatik (tektonik) dan di sebelah timur pulau Halmahera juga menunjukkan adanya aktifitas gempa di wilayah 
tersebut, hal ini dikarenakan adanya tunjaman lempeng Pasifik ke bawah lempeng mikro Halmahera. Wilayah selatan dari provinsi Maluku Utara juga terdapat sumber gempa bumi yang mengarah sesar Sorong-Sula, diwilayah ini terdapat percabangan dari wilayah timur kemudian bercabang menjadi dua bagian disebelah barat kepulauan Sula sehingga membentuk sesar Sula-Sorong bagian utara dan Sula Sorong bagian selatan. Namun kejadian gempa bumi di wilayah ini tidak terlalu besar sebagaimana terjadi di wilayah Maluku. Keaktifan gempa bumi di kawasan utara Pulau Halmahera, dipengaruhi oleh sistem tatanan tektonik lempeng Filipina di sebelah timur dan seblah lempeng laut Maluku bagian barat. Berbeda dengan kawasan di bagian selatan, di kawasan bagian utara ini lebih dominan oleh gempa bumi yang berkedalaman menengah $(30 \leq \mathrm{h} \leq 60)$ dan gempa bumi dalam $(\mathrm{h}>300$ $\mathrm{km})$.

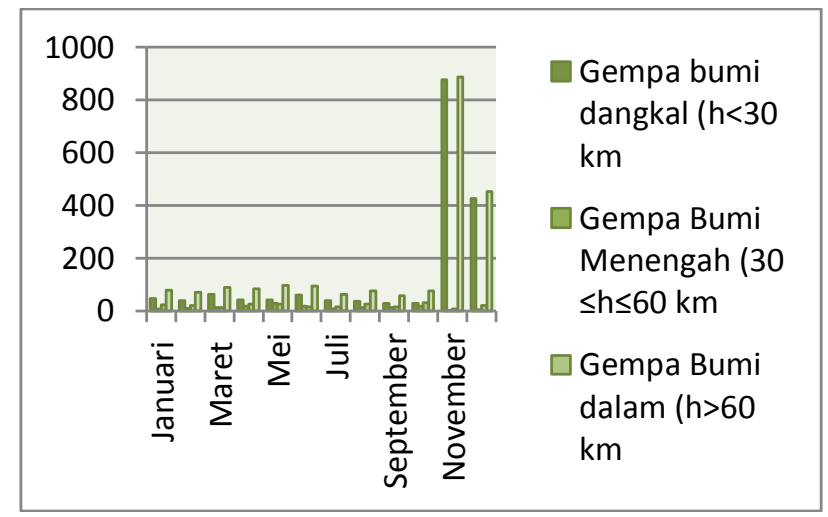

Gambar 3. Histrogram Jumlah Kejadian Gempa Per Bulan Berdasarkan Kedalaman

\section{B. Kejadian Gempa Bumi}

Selama tahun 2015 terdapat 56 kali gempa bumi yang di rasakan secara keseluruhan dan 42 kali yang di rasakan pada bulan november dan 1 kali di rasakan pada bulan april hingga september, dan yang tidak di rasakan oleh manusia berjumlah secara keseluruhan 20.51 kejadian dan peningkatan gempa yang tidak terasakan 844 kali di bulan november dan 56 kali sebagai terkecil pada bulan september 56 kali.

Kejadian gempa bumi di kelompokan menjadi 6 segmen, pembagian segmen ini berdasarkan pada kawasan rawan terjadinya gempa bumi. Segmen pulau Halmahera, segmen subduksi Halmahera-laut Maluku, segmen pulau Morotai, segmen swarm Jailolo-Halmahera Barat dan segmen sesar Sula-Sorong di Halmahera Selatan.

\section{Gempa Bumi di Pulau Halmahera dan Maluku}

Gempa bumi di pulau Halmahera umunya terjadi karena desakan lempeng Pasifik melalui lempeng Caroline di timur Halmahera (utara timur Papua), mikro lempeng (kecil) ini mendesak ke arah barat dan menunjam di bawah busur Halmahera. Adapun gempa bumi yang di rasakan dapat di jelaskan dalam berikut ini: (1) Gempa Bumi dengan kekuatan mencapai 4,1 magnitudo terjadi 31 januari 2015 pukul 06.55.46 Wit dengan pusat gempa berada 0.22 Lintang utara-128.68 Bujur timur dan kedalaman $47 \mathrm{~km}$, kekuatan gempa ini dapat di rasakan (Patani) Kabupaten Halmahera Tengah (2) Gempa bumi mempunyai kekuatan 4,3 magnitudo terjadi 14 juli 2015, pukul 23.20.55 Wit dengan pusat gempa bumi berada di koordinat 0.54 lintang utara dan 127.68 bujur timur dan kedalaman $10 \mathrm{~km}$ dirasakan di Tidore dan Ternate (3) Gempa bumi kekuatan 3,5 magnitudo terjadi pada tanggal 8 mei 2015, pukul 16.43.49 Wit dengan pusat gempa bumi berada 1.48 lintang utara dan 127.55 bujur timur dan kedalaman $10 \mathrm{~km}$ di rasakan di Ternate (4) Gempa bumi empat 
kali rentang terjadi 25 februari 2015 dengan kekuatan berkisar 3,2-3,8 terjadi diantara 09.00.43 hingga 10.10.53, dengan pusat gempa bumi sekitar Jailolo Kabupaten Halmahera Barat, kedalaman mencapai $10 \mathrm{~km}$ pada koordinat geografis 0.97 lintang utara sampai 127.22 bujur barat, 0.95 lintang utara. Terjadi lagi peningkatan kedalaman gempa bumi mencapai $36 \mathrm{~km} \mathrm{4,0} \mathrm{magnitudo,} 23$ oktober 2015 pukul 19.45.57 Wit masih tetap di rasakan sekitar Jailolo Kabupaten Halmahera Barat pada koordinat 0.94 lintang utara- 127.47 bujur barat.

Kawasan laut Maluku dikenal sebagai salah satu kawasan dengan tingkat seismisitas yang paling aktif di Indonesia (Hall, 2009). Aktifitas seismik ini berkaitan dengan zona subduksi ganda, yaitu subduksi dari lempeng Pasifik melalui busur Halmahera yang menunjam kearah barat, dan subduksi lempeng Eurasia melalui busur Sangihe yang menunjam ke arah timur, sehingga posisi lempeng laut Maluku yang berada di tengah seakan-akan terjepit karena desakan dari dua busur kepulauan yang berlawanan arah.

Terdapat beberapa gempa bumi terasa di wilayah ini antara lain: (1) Gempa bumi mempunyai kekuatan 4,5 magnitudo dapat di rasakan di pulau Morotai. Kejadian ini 20 januari 2015, pukul 20.10.39 wit, kejadian ini berada di koordinat geografis antara 2.24 lintang utara-125.58 bujur timur kedalaman mencapai $24 \mathrm{~km}$ (2) Kekuatan gempa bumi mencapai 5.4 magnitudo, terjadi 25 januari 2015, pukul 18.20 .55 wit, pusat gempa berada diantara 1.89 lintang utara dan 126.35 bujur timur, kedalaman gempa $10 \mathrm{~km}$ dapat dirasakan di kota Ternate. Dari tanggal 25 januari sampai 8 november 2015 kekuatan gempa sangat bervariasi 6,2 5,6 6,3 5,6 dan 5,0 magnitudo ini masih tetap di rasakan di kota Ternate.

\section{Gempa Bumi Laut Maluku Dan Busur Halmahera}

Gempa bumi yang terjadi di daerah ini tidak jauh dari daerah subduksi sehingga sangat berkaitan dengan interaksi antara busur Halmahera dan lempeng laut Maluku (De Grave dan Fransen, 2011). Gempa bumi ini terjadi sangat beragam hal ini disebabkan salah satu dari lempeng laut Maluku menukiik kearah timur di bawah busur Halmahera menembus sampai kedalaman $500 \mathrm{~km}$. Di sisi lain pada kedalaman dangkal busur Halmahera menembus sampai kedalaman $500 \mathrm{~km}$, pada kedalaman dangkal busur Halmahera tersubduksi kearah barat dan menunjam kelempeng laut Maluku. Gempa bumi yang berkedalaman menengah dan dalam terjadi pada struktur lempeng laut Maluku, dan gempa bum berkedalaman dangkal terjadi struktur subduksi busur Halmahera. Gempa bumi yang terjadi di daerah ini yaitu: (1) Gempa bumi mempunyai kekuatan 4,5 dan 3,6 dan 4,8 magnitudo terjadi tanggal 25 mei 23 juli dan 16 agustus 2015, berada pada skala III-IV (Modified mercally intensity), kejadian ini terjadi dengan masing-masing kedalaman mencapai $10 \mathrm{~km}$ dan $28 \mathrm{~km}$ terutama di wilayah Jailolo Kabupaten Halmahera Barat, dan berada pada koordinat diantara 1.00 lintang utara dan 127.16 bujur timur (2) 20 agustus terjadi lagi gempa bumi, kekuatan mencapai 5,7 magnitudo 16 oktober 2015 4,6 magnitudo dan 5,0 magnitudo, 17 oktober serta kedalaman berkisar diantara 10-50 km yang dapat di rasakan di kota Ternate, kejadian ini di koordinat 1.94 lintang utara dan 127.24 bujur timur. 


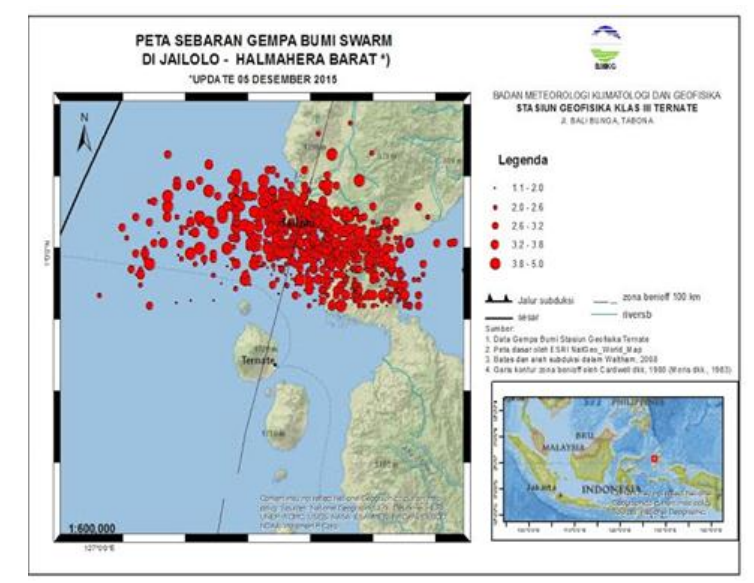

Gambar 4. Peta sebaran gempa bumi swarm di Jailolo (Halmahera Barat), data sebaran pusat gempa yang ditampilkan dengan berwarnah merah pada tanggal 5 Desember 2015 (sumber Badan Meteorologi Klimatologi dan Geofisika Stasiun Ternate 2016).

Aktifitas gempa bumi di sekitar Jailolo Kabupaten Halmahera Barat mulai teridentifikasi pada tanggal 8 november 2015 dengan 94 kali gempa bumi dengan kekuatan kurang lebih daru 5,0 magnitudo dan pusat gempa yang terkosentrasi di wilayah Jailolo dan sekitarnya. Fenomena ini berlangsung hingga kurang lebih dua bulan setelah sampai pada tanggal 31 desember 2015 telah tercatat 1.161 gempa bumi.

Tercatat sebanyak 48 kali kejadian gempa bumi yang cukup signifikan dan mengguncan sehingga dapat dirasakan mencapai skala III-IV (Modified mercally intensity) di Jailolo serta menimbulkan kerusakan dan bahkan dirasakan di Ternate pada skala II-III (MMI). Bentuk kerusakan bangunan rumah termuat dalam gambar berikut ini.

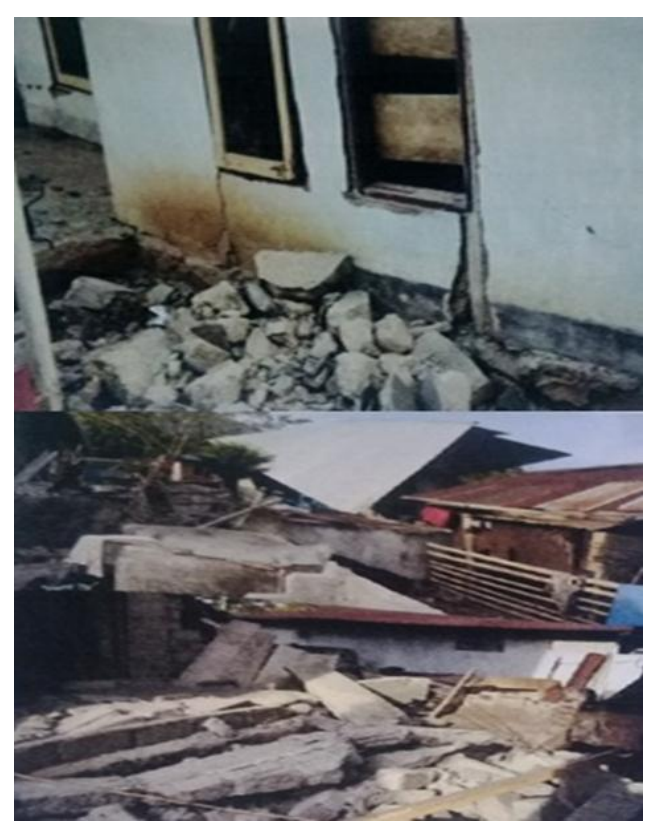

Gambar 5. Kerusakan bangunan rumah akibat gempa bumi di kecamatan Jailolo Selatan Kabupaten Halmahera Barat di bulan November 2015

Akibat dari kekuatan gempa bumi tersebut mengakibatkan kerusakan ringan dan berat, umumnya rumah warga yang mengalami kerusakan berat adalah bangunan yang sudah 
tua dan di bahwa standar konstruksi bangunan rumah pada umunya. Kerusanakan bangunan rumah meliputi terparah di Desa Bobanehena terdapat 157 bangunan rusak berat, dan 136 rusak sedang dan 350 bangunan rusak ringan. Di Desa Idamdehe 13 bangunan rusak berat 18 rusak sedang dan 30 bangunan rusak ringan. Kerusakan juga terjadi di jalan baru 8 bangunan rusak berat dan 28 bangunan rusak ringan, sedangkan di Desa Guaeria terdapat 7 bangunan rusak berat, 25 rusak sedang dan 19 bangunan rusak ringan.

Hall dan Spakman (2005) menjelaskan bahwa gempa bumi dapat berasosiasi dengan aktivitas magmatik (vulkanik) maupun non magmatik (tektonik), hal ini di dukung oleh data sebagai berikut: (1) Wilayah Jailolo masuk dalam zona Benioff kedalaman $100 \mathrm{~km}$, yang mana lajur subduksi dari laut Maluku menunjam dibawah struktur mikro lempeng Halmahera dan membentuk sudut tuktik yang tajam. Pada kedalaman tertentu, volatile air yang terbawa oleh kerak samudra (laut Maluku) akan mendorong terbentuknya pelelehan sebagian (partial melting) proses inilah yang menjadi cikal bakal terbentuknya magma dilapisan atasnya (Gunawan et al., 2016). Pada beberapa kasus, intrusi magma pada kerak batuan menyebabkan gempa bumi skal kecil yang bergerombol (2) Data dari Badan Geologi menyebutkan bahwa di sekitar Jailolo terdapat sebuah gunung tipe strato volcano yang membentuk semenanjung disebelah barat teluk Jailolo. Gunung ini sudah lama tidak mengalami erupsi, hal ini dibuktikan dengan adanya bekas aliran lava muda disisi timur dan sumber air panas di beberapa tempat, data ini mengungkapkan bahwa aktifitas magmatik sebagai pembangkit gempa bumi swam sangat mungkit terjadi di kawasan ini (3) Data dari Badan Geologi menyebutkan mahwa material bebatuan di wilayah Jailolo dan sekitarnya cukup heterogen terdiri dari batu pasir, nafal, tufa, konglomerat, batu gamping (Ramadhan et al., 2012; Sarmili, 2015). Bebatuan ini menyebabkan tingkat rigiditas bebatuan yang rendah atau mudah rapuh. Beberapa kasus menunjukan bahwa aktivitas swarm dapat terjadi di kawasan non volkanik seperti di kawasan dengan krakteristik bebatuan yang rapuh sehingga mudah terjadi retakan (fractures), pada kasus gempa bumi swarm Jailolo ditemukan sejumlah fractures di beberapa kawasan dan sekitarnya. Dalam peta geologi regional Halmahera, secara geologi pulau Halmahera adalah sesar yang berarah barat-timur yang dominan di (formasi Tinteng dan formasi Kayasa), kedua formasi ini masih dijumpai adanya batuan sedimen klastik, batuan beku andesit dan basalt serta antiklin dan sinklin berarah bagian selatan yang tersebar pada (formasi Bacan dan formasi Weda) lebih dominan batuan sedimen klastik seperti batu pasir, napal, tufa, konglomerat dan batu gamping (Sufni Hakim dan Hall, 1991; Nichols dan Hall, 1991). Jika data gempa bumi tahun 2015 di hubungkan dengan peta geologi regional, hal ini memiliki keterkaitan terutama energi gempa bumi yang terakumulasi di formasi Bacan lebih dominan terdapat struktur geologi, menyebabkan daerah ini lemah dan mudah mengalami kerusakan terutama adanya guncangan gempa bumi yang melewati zona-zona struktur (4) Gempa bumi terus menerus dengan kekuatan yang sama dan terkosentrasi pada suatu wilayah di jalur gunung api adalah hal yang biasa terjadi menjelang letusan gunung api. Namun faktanya tidak ada gunung api yang mengalami erupsi secara signifikan. Hal ini menunjukan bahwa gempa bumi swarm di Jailolo dengan kedalaman rata-rata $10 \mathrm{~km}$ tidak mencirikan sebuah gempa bumi vulkanik (5) Dari hasil analisis mekanisme sumber pada gempa bumi signifikan yang berkaitan dengan gempa bumi swarm di Jailolo menunjukan bahwa gempa bumi ini dibangkitkan oleh sebuah mekanisme patahan turun normal (fault) dengan kecendrungan strike berarah utaraselatan. Dari hasil analisis ini diperkirakan ada sebuah mekanisme depresi lokal yang terjadi di bawah permukaan zona gempa bumi. 


\section{E. Gempa Bumi Halmahera Bagian Selatan}

Kawasan Halmahera bagian selatan diapit oleh zona subduksi di sisi sebelah barat dan zona sesar di sisi sebelah selatannya, menjadikan kawasan dengan sistem tektonik yang lebih rumit. Di sisi sebelah barat dari kawasan ini terdapat laut Maluku menunjam kearah timur, walapun lajur subduksi ini mempunyai trend yang menjauh yang membelok kearah barat, namun dampak dari gempa bumi yang terjadi di zona subduksi ini sangat berpengaruh terhadap seismisitas kawasan. Selain zona subduksi kawasan Halmahera bagian selatan juga di belah oleh sesar aktif (leftlateral) yang memanjang dari kawasan kepala burung Papua, melewati kepulauan Sula dan berakhir di sekitar kepulauan Bangai di Sulawesi Tengah. Terdapat 2 gempa dan terasa di kawasan ini selama di tahun 2015 diantaranya; Gempa bumi yang berkekuatan 3,7 magnitudo terdapat di bulan juni pukul 18.18 .33 wit dengan pusat gempa bumi berada di koordinat geografis 0.86 lintang selatan dan 128.32 bujur timur, kedalam gempa ini sekitar $10 \mathrm{~km}$ yang dapat di rasakan secara langsung oleh masyarakat di Kabupaten Halmahera Selatan, dan berada pada skala II (Modified mercally intensity). Kekuatan gempa bumi yang juga terjadi 4,6 magnitudo, 27 juli, pukul 17.52.19 wit kedalaman mencapai $10 \mathrm{~km}$ dan titik koordinat geografis menunjukkan 0.88 lintang selatan dan 126.82 bujur timur dan ini berada di skala I-II (Modified mercally intensity), dan di rasakan di Labuha Kabupaten Halmahera Selatan.

\section{KESIMPULAN}

Wilayah Maluku Utara merupakan daerah tektonik yang sangat aktif dan kompleks di kawasan ini. karena di sebakan hasil interaksi dari ketiga lempeng besar yaitu lempeng Pasifik, lempeng Eurasia dan lempeng Indo-Australia di kawasan Maluku Utara yang berlangsung dalam jangka waktu cukup lama. Pertemuan dari beberapa lempeng tektonik dapat menyebabkan saling mendorong antara satu dengan lainnya, menjadikan kawasan Maluku Utara dan Halmahera akan aktif sistem sesar terutama terjadi pada busur kepulauan Halmahera.

\section{DAFTAR RUJUKAN}

Buletin Gempa Bumi dan Tsunami 2015. Badan Meteorologi Klimatologi dan Geofisika Stasiun Geofisika Ternate, Januari 2016.

Ballantyne, P., 1991. Petrological Constraints Upon The Provenance and Genesis of the East Halmahera Ophiolite. J. Sout heast Asian Earth Sci., Orogenesis In Action Tectonics and Processes at the West Equatorial Pacific Margin 6, 259-269. doi:10.1016/07439547 (91) 90072-6.

Condie, K.C., 2016. A planet in transition: The onset of plate tectonics on Earth between 3 and 2 Ga Geosci. Front. doi:10.1016/j.gsf.2016.09.001.

De Grave, S., dan Fransen, C., 2011. Carideorum Catalogus: the recent species of the dendrobranchiate, stenopodidean, procarididean and caridean shrimps (Crustacea: Decapoda). Zool. Meded. 85, 195.

Gunawan, E., Ghozalba, F., Syauqi, Widiastomo, Y., Meilano, I., Hanifa, N.R., Daryono, Hidayati, S., 2017. Field Investigation of the November to December 2015 Earthquake Swarm in West Halmahera, Indonesia. Geotech. Geol. Eng. 35, 425-432. doi:10.1007/s10706-016-0117-4.

Gunawan, E., Kholil, M., Meilano, I., 2016. Splay-fault rupture during the 2014 Mw7.1 Molucca Sea, Indonesia, earthquake determined from GPS measurements. Phys. Earth Planet. Inter. 259, 29-33. doi:10.1016/j.pepi.2016.08.009.

Hall, R., 2009. Indonesia, geology. Encycl. Isl. Univ Calif. Press Berkeley Calif. 454-460.

Hall, R., 2000. Neogene history of collision in the Halmahera region, Indonesia. 
Hall, R., Spakman, W., 2015. Mantle Structure and Tectonic History of SE Asia. Tectonophysics 658, 14-45. doi:10.1016/j.tecto.2015.07.003.

Hillis, R.R., dan Muller, R.D., 2003. Evolution and Dynamics of the Australian Plate. Geological Society of America.

Lourenço, D.L., Rozel, A., dan Tackley, P.J., 2016. Melting-Induced Crustal Production Helps Plate Tectonics On Earth-like Planets. Earth Planet. Sci. Lett. 439, 18-28. doi:10.1016/j.eps1.2016.01.024.

Nakagawa, T., dan Spiegelman, M.W., 2017. Global Scale Water Circulation in the Earths Mantle: Implications for the mantle water budget in the early Earth. Earth Planet. Sci. Lett. 464, 189-199. doi:10.1016/j.epsl.2017.02.010.

Nichols, G.J., dan Hall, R., 1991. Basin Formation and Neogene sedimentation in a backarc setting, Halmahera, Eastern Indonesia. Mar. Pet. Geol. 8, 50-61. doi:10.1016/02648172(91)90044-2.

Ramadhan, Y., Diningrat, W., Sutrisno, L., Tasrif, A., dan Bogie, I., 2012. Geoscientific Survey Results From the Jailolo Geothermal Field, Northern Halmahera, Indonesia.

Sarmili, L., 2015. Hydrothermal Mineralization in jailolo Waters, West Halmahera, North Maluku Province. Bull. Mar. Geol. 30, 35-43.

Sufni Hakim, A., dan Hall, R., 1991. Tertiary Volcanic Rocks From The Halmahera arc, Eastern Indonesia. J. Southeast Asian Earth Sci., Orogenesis In Action Tectonics and Processes at the West Equatorial Pacific Margin 6, 271-287. doi:10.1016/07439547(91)90073-7.

Sulaeman, C., dan Cipta, A., 2012. Model Intensitas Gempa Bumi di Maluku Utara. J. Lingkung. Dan Bencana Geol. 3, 79-88.

Widiwijayanti, C., Mikhailov, V., Diament, M., Deplus, C., Louat, R., Tikhotsky, S., dan Gvishiani, A., 2003. Structure and Evolution of the Molucca Sea Area: constraints based on interpretation of a combined sea-surface and satellite gravity dataset. Earth Planet. Sci. Lett. 215, 135-150. doi:10.1016/S0012-821X(03)00416-3. 